\title{
Phytochemical, Morphological, and Molecular Evidence for the Occurrence of the Neotropical Liverwort Plagiochila stricta in the Canary Islands, New to Macaronesia
}

DAVID S. Rycroft AND W. JOHN COLE

Department of Chemistry, University of Glasgow, Glasgow G12 8QQ, Scotland, U.K. e-mail: D.Rycroft@chem. gla.ac.uk

Jochen HeinRIChS AND Henk GROTh

Albrecht-von-Haller-Institute für Pflanzenwissenschaften, Abteilung Systematische Botanik, Universität Göttingen, Untere Karspüle 2, 37073 Göttingen, Germany; e-mail: jheinri@gwdg.de

CARSTEN RENKER

Institut für Ökologie, Universität Jena, Dornburger Strasse 159, 07743 Jena, Germany

ThOMAS PRÖSCHOLD

Botanisches Institut I, Universität zu Köln, Gyrhofstrasse 15, 50931 Köln, Germany

Abstract. Plant material from the Canary Islands similar to Plagiochila spinulosa (Dicks.) Dumort. has been identified as the Neotropical liverwort P. stricta Lindenb. The secondary metabolite profiles of $\mathrm{CDCl}_{3}$ extracts of both Neotropical and Macaronesian specimens of $\mathrm{P}$. stricta are distinct from those of $\mathrm{P}$. spinulosa in containing alloocimene and neoalloocimene as the principal monoterpenes rather than $\beta$-phellandrene; the two species also show differences in the 9,10dihydrophenanthrenes and other aromatic compounds present. Phylogenetic analyses of ITS $n r D N A$ sequence variation place P. spinulosa sister to P. stricta. Morphologically, P. stricta from Tenerife is distinguished most easily from P. spinulosa by the scarcely decurrent antical leaf margin.

There is current interest in the potential of bryophyte studies to provide biogeographical insight into genetic diversity, cryptic speciation, and origins of plant populations, especially on islands within areas such as Macaronesia (Freitas \& Brehm 2001), and in the application thereto of phylogenetic analyses of DNA sequence variation or of other DNA-derived data (Shaw 2001). Adequate knowledge of the relevant taxa is essential for such studies and, as in the case of the difficult and numerous genus Plagiochila, is not always available.

The bryophyte checklist for the Canary Islands (Dirkse et al. 1993) recorded five Plagiochila species on Tenerife: P. dubia Lindenb. \& Gottsche [now identified as $P$. virginica A. Evans (Heinrichs et al. 2002b)], P. exigua (Taylor) Taylor, P. killarniensis Pearson [synonymous with $P$. bifaria (Sw.) Lindenb. (Heinrichs et al. 1998b)], P. punctata (Taylor) Taylor, and P. spinulosa (Dicks.) Dumort. Following our phytochemical studies of Plagiochila specimens from Madeira that resulted in the discovery of Plagiochila retrorsa Gottsche and of a still unidentified Plagiochila with dentate leaves (Rycroft et al. 2001), herbarium specimens of some small plants from the Canary Islands that had been determined as $P$. spinulosa were analyzed phytochemically. The NMR profiles were different from those of specimens of $P$. spinulosa from the British Isles (Connolly et al. 1999), but had similarities to those of $P$. retrorsa Rycroft et al. 2001) and $P$. papillifolia Steph. (Heinrichs et al. 2002c) in respect of the presence of compounds 1 and 4 (chemical compounds and structures are identified by numerals printed bold in Fig. 1).

Against this background, stands of a Plagiochila that superficially resembled $P$. spinulosa (with dentate, sometimes caducous leaves) were observed in three areas of humid laurel forest during the British Bryological Society Spring 2001 Meeting on Tenerife (Blockeel 2002). However, compared to British material, the facies of the plant was different and the odor of the crushed plant in the field was spicier. In addition, the preferred habitat appeared to be excessively shaded compared to that of $P$. spinulosa in the British Isles.

These observations prompted us to investigate the plants further-we were able to capitalize on phytochemical and molecular data that we had already obtained from Neotropical material of $P$. stricta Lindenb., a species whose morphology was 
<smiles>[R]c1cc(CCc2ccc(O)c3c2C(=O)O[CH]O3)ccc1OC</smiles><smiles>COc1ccc2c(c1)CCc1cc(O)c(O)cc1-2</smiles>

2

$1 \quad \mathrm{R}=\mathrm{H}$

$6 \mathrm{R}=\mathrm{OH}$<smiles>COc1cc2c(cc1OC)-c1c(cccc1OC)CC2</smiles>

3<smiles>COc1cc2c(cc1O)CCc1cccc(OC)c1-2</smiles>

4<smiles>COc1ccc2c(c1)CCc1ccc(OC)c(O)c1-2</smiles>

5<smiles>COc1ccc2c(c1)CCc1cc(O)c(OC)c(OC)c1-2</smiles>

7<smiles>COc1cc2c(c(C)c1C(C)=O)OCO2</smiles>

8<smiles>COc1cc(OC)c(C(C)=O)c(OC)c1C</smiles><smiles>C/C=C(C)/C=C/C=C(C)C</smiles>

10<smiles>C=C/C(C)=C/CC=C(C)C</smiles>

12<smiles>C=C/C(C)=C\CC=C(C)C</smiles>

13<smiles>C=C1C=CC(C(C)C)CC1</smiles>

14<smiles>CC1=CCC(=C(C)C)CC1</smiles>

15

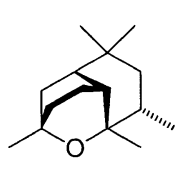

16<smiles>CC1=CC[C@H]2C(CC1)C2(C)C</smiles>

17<smiles>C=C1CC[C@@H]2[C@H]([C@@H]1C)[C@H]1C(C)(C)[C@@H]2CC[C@]1(C)O</smiles>

18

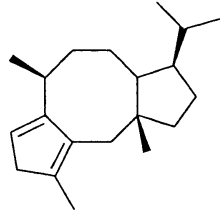

19

Figure 1. Chemical structures, identified by the bold numerals that are used in the text and Table 1.

recently redescribed (Heinrichs et al. 1998a), and to extend our knowledge of the molecular phylogeny of the genus Plagiochila (Heinrichs et al. 2002a,b; Renker et al. 2002). Here we report details of work that established the presence of P. stricta in the Canary Islands archipelago.

\section{Materials AND Methods}

Plant material.-Details of four of the specimens used are in the caption to Table 1. A fifth, from which DNA was extracted, was Drehwald 3920, Tenerife, 24th December 1999 (GOET). Other material used for illustration is mentioned in the caption to Figure 2.
Phytochemistry. - The lipophilic secondary metabolites of $P$. stricta specimens were determined using NMR and GC-MS profiling of deuterochloroform extracts (Rycroft 1996, 1998). Upper parts of a few shoots were selected and inspected carefully to remove other species. The dry plant material was ground together with a small quantity of broken glass and extracted with $\mathrm{CDCl}_{3}$ (ca $0.7 \mathrm{ml}$ ). Proton NMR spectra of the filtered solutions were measured at $400 \mathrm{MHz}$, with chemical shifts ( $\delta \mathrm{ppm})$ reported relative to internal tetramethylsilane. Concentrations were measured by comparing signal integrals with the calibrated residual proton signal of the solvent and converted to weight percentages extracted from the dry plant. The same solutions were used for GC-MS, as described previously (Rycroft \& Cole 2001). GC-MS of the extracts after acet-

TABLE 1. Compounds in $\mathrm{CDCl}_{3}$ extracts of Plagiochila stricta. The structure numbers correspond with Fig. 1. The specimens (all in GOET) are i): Rycroft 01035, Tenerife, 19 February 2001, $30 \mathrm{mg}$ extracted 27 February 2001; ii): Rycroft 01071, Tenerife, 22 February 2001, 35 mg extracted 26 July 2001; iii): Holz EC-01-478, Ecuador, May 2001, $23 \mathrm{mg}$ extracted 5 June 2001; iv): Heinrichs et al. 4401, Costa Rica, September 1999, 17 mg extracted 16 May 2000. The absolute amounts of compounds extracted from the specimens were determined from proton NMR spectra and converted to $\% \mathrm{w} / \mathrm{w}$ of the dried specimens extracted. The amounts are indicated as follows: "-": not detected; "tr.": trace; “+": 0.04-0.1\%; “++": 0.2-0.9\%; “+++": 1-2\%; “++++": 3-4\%; parentheses denote detection by GCMS only.

\begin{tabular}{|c|c|c|c|c|c|}
\hline \multirow[b]{2}{*}{ Compound } & \multirow[b]{2}{*}{ Structure } & \multicolumn{4}{|c|}{ Specimen number } \\
\hline & & (i) & (ii) & (iii) & (iv) \\
\hline methyl 4-hydroxy-4'-O-methyllunularate & 1 & ++++ & ++++ & ++++ & ++ \\
\hline 3,7-dimethoxy-9,10-dihydrophenanthren-2-ol & 2 & + & + & ++ & + \\
\hline 2,3,5-trimethoxy-9,10-dihydrophenanthrene & 3 & + & + & + & + \\
\hline 3,5-dimethoxy-9,10-dihydrophenanthren-2-ol & 4 & ++ & ++ & - & ++ \\
\hline 3,7-dimethoxy-9,10-dihydrophenanthren-4-ol & 5 & ++ & ++ & ++ & - \\
\hline methyl 3',4-dihydroxy-4'-O-methyllunularate & 6 & (tr.) & (tr.) & ++ & + \\
\hline alloocimene & 10 & +++ & ++ & ++ & ++ \\
\hline neoalloocimene & 11 & +++ & ++ & +++ & ++ \\
\hline terpinolene & 15 & $(+)$ & $(+)$ & $(+)$ & $(+)$ \\
\hline peculiaroxide & 16 & ++ & ++ & + & ++ \\
\hline bicyclogermacrene & 17 & +++ & ++ & ++ & + \\
\hline spathulenol & 18 & - & ++ & + & + \\
\hline fusicoccadiene & 19 & $(+)$ & - & $(++)$ & $(++)$ \\
\hline
\end{tabular}




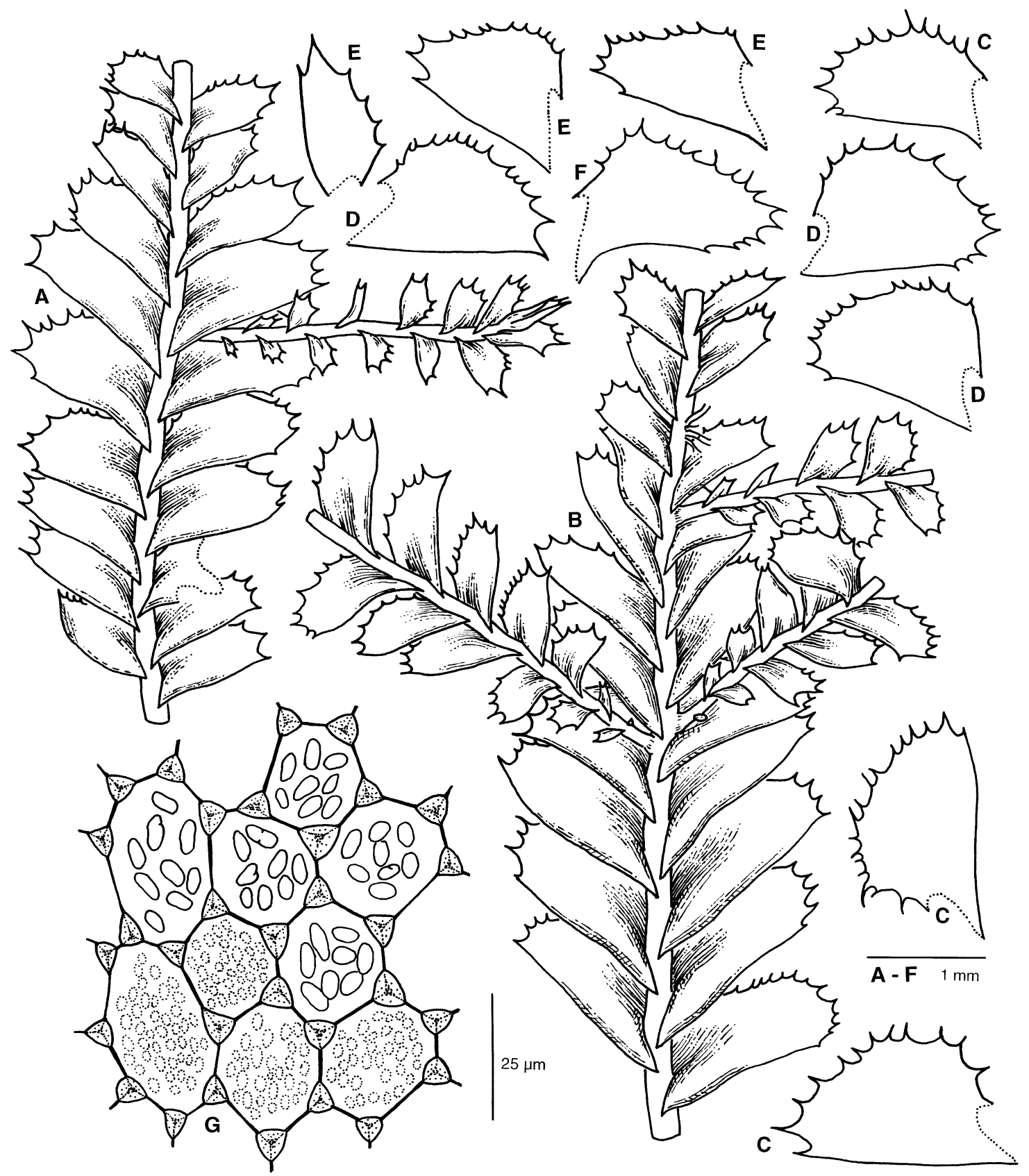

FIgURE 2. Plagiochila stricta Lindenb. - A, B. Parts of shoots, dorsal view. - C-F. Leaves. - G. Cells from leaf center, with oil bodies or papillae. (A, D, G from Tenerife, Rycroft 01071 [GOET]; B, C from Tenerife, Drehwald 3929 [GOET]; E from Jamaica, Underwood 1410 [GOET]; F from Ecuador, Holz EC-01-478 [GOET]).

ylation was also undertaken in order to distinguish compounds with hydroxyl groups that could be acetylated. Compounds were identified by comparison with authentic compounds or with data either in the literature or from our earlier work. There is much confusion in the literature concerning the identification and stereochemistry of alloocimene (10) and neoalloocimene (11). Although this situation was highlighted and clarified many years ago (Crowley 1968), the problem continues to manifest itself. In contrast to the information presented in a recent com- pilation of GC-MS data (Adams 1995), alloocimene is in fact $(4 E, 6 E)$-2,6-dimethyl-2,4,6-octatriene (Combined Chemical Dictionary 2001), whereas neoalloocimene is (4E,6Z)-2,6-dimethyl-2,4,6-octatriene and has the shorter GC retention time, a consequence of its lower boiling point.

DNA extraction, PCR amplification, cloning, and sequencing.-The procedures leading to the sequences of the nrDNA internal transcribed spacer (encompassing the ITS1-, 5.8S- and ITS2-regions, and designated ITS here- 
after) were as described previously (Heinrichs et al. $2002 b$ ). GenBank accession numbers of the four $P$. stricta sequences are AJ416646 (766 bases, Heinrichs et al. 4401), AJ416647 (764 bases, Holz EC-01-478), AJ416648 (768 bases, Rycroft 01071), AJ416649 (769 bases, Drehwald 3920). Details of the other eleven sequences used have been published (Heinrichs et al. 2002a).

Phylogenetic analyses.-Phylogenetic trees were inferred by using PAUP* (Swofford 2000) to apply distance (neighbor-joining: NJ), maximum parsimony (MP) and maximum likelihood (ML) criteria to a data set of 802 aligned positions of 15 ITS nrDNA sequences (Herbertus subdentatus, four specimens of $P$. stricta, and 10 other species of Plagiochila; alignment available from J.H.; initially the alignment resulted in 876 positions, but 74 , mainly belonging to inserts of the outgroup, were excluded from the analysis, to avoid producing artificially long branches). Modeltest 3.04 (Posada \& Crandall 1998) was used to choose the evolutionary model that fits the data best; this program employs two statistics: the likelihood ratio test (LRT) and the Akaike information criterion (AIC, Akaike 1974). The model selected by the hierarchial LRT was the HKY85 model (Hasegawa et al. 1985), with estimates of the transition/transversion ratio and of the gamma shape parameter for among site variation $(\mathrm{G})$ calculated from the data set. The ML method (applied to the HKY 85+G model) was used for phylogenetic analyses.

The confidence of branching was assessed using 100 bootstrap resamplings in ML analysis (using the HKY 85+ $\mathrm{G}$ model, with 10 addition-sequence replicates) and 1,000 bootstrap resamplings in distance (NJ method with the HKY85+G model) and unweighted MP analysis (with 10 addition-sequence replicates) of the data set (Felsenstein 1985).

TreeView (version 1.6.2, Page 1996) was used to modify the tree file of the "best tree" in order to generate user-defined trees. To assess user-defined topologies relative to the "best tree," the sequence data file and the tree files were loaded into PAUP* and tested according to Kishino and Hasegawa (1989); comparisons were based on ML (with the HKY $85+\mathrm{G}$ model of evolution selected by Modeltest 3.04) and MP criteria.

\section{RESULTS AND DISCUSSION}

Morphological differentiation.-Plagiochila stric$t a$, typified on Swartz material from Jamaica, is a widespread, Neotropical, montane species. It was redescribed and illustrated recently (Heinrichs et al. $1998 a$ ); several heterotypic synonyms were identified and subsequently a further synonym, P. elegantula Herzog, has been reported (Heinrichs et al. 2001). Plants from Tenerife are illustrated in Figure 2. All the material of P. stricta observed on Tenerife was sterile and generally less robust than that from the Neotropics.

Material like that now identified as $P$. stricta has been determined previously as $P$. spinulosa. The antical leaf margin of $P$. spinulosa is long-decurrent (Paton 1999) whereas in the Tenerife taxon it is barely or not decurrent. In the British Isles, this character would be sufficient to refer the material to $P$. punctata, but on Tenerife that species is typically very robust, with a facies more akin to that of vigorous $P$. spinulosa in the British Isles. The tendency of many of the shoots to have leaves that lie more or less flat and spread out, rather than tending to be revolute and retrorse as in $P$. spinu$l o s a$, contributes to the distinctive facies of $P$. stric$t a$ on Tenerife, where it grew in thin mats close to the substrate rather than in thick cushions. The leaf cuticle papillae of both $P$. stricta and $P$. spinulosa may exhibit different shapes, depending on the proportions of the cell dimensions. Distinctly elongate cells tend to have ellipsoidal to striate papillae whereas round to ellipsoidal papillae are typical of more or less isodiametric cells. Papillae in P. spinulosa are usually loosely spaced whereas those in $P$. stricta are often densely spaced. Elongate, triangular to ciliate teeth are sometimes present at the postical leaf base of Neotropical P. stricta and can be found in Tenerife material, though infrequently. The ill-defined vitta of $P$. stricta is not well developed in Tenerife material. Although perianths were not observed on Tenerife, those occurring in Neotropical $P$. stricta have a mouth with elongate triangular to long ciliate teeth; $P$. spinulosa has shorter teeth on the perianth mouth.

Ecological discrimination.-The preferred habitat of P. stricta on Tenerife, in contrast to that of $P$. spinulosa in the British Isles (and, indeed, to that of $P$. bifaria, $P$. punctata, and P. exigua on Tenerife), appeared to be deeply shaded and humid, in laurisilva localities sometimes also occupied by Heteroscyphus denticulatus (Mitt.) Schiffn. and Trichomanes speciosum Willd., species with habitat requirements that are different from, and much more demanding than, those of $P$. spinulosa. Trichomanes speciosum was described recently as "the most shade tolerant of all plant species so far studied" (Johnson et al. 2000) and the sporophyte generation is restricted to sheltered and extremely humid sites (Ratcliffe et al. 1993). While it is not the intention to suggest that $P$. stricta is equally demanding, it was striking that more open positions where there was luxuriant growth of $P$. punctata (and where $P$. spinulosa might have been expected based on experience in the British Isles) were not occupied by $P$. stricta.

Phytochemical distinction.-Table 1 shows the major aromatic and terpenoid compounds observed in the $\mathrm{CDCl}_{3}$ extracts of four specimens of P. stric$t a$. The profile with respect to the aromatic compounds is not uniform, although the two Tenerife specimens are rather similar. This is evident from the proton NMR spectra of the four extracts in Figure 3, where the methoxyl region is presented so as to ease comparison with the same region of spectra of $P$. retrorsa extracts (Rycroft et al. 2001). One $P$. spinulosa extract is included in Figure 3 and is readily seen to be very different in detail, although the same types of compound are among those pre- 

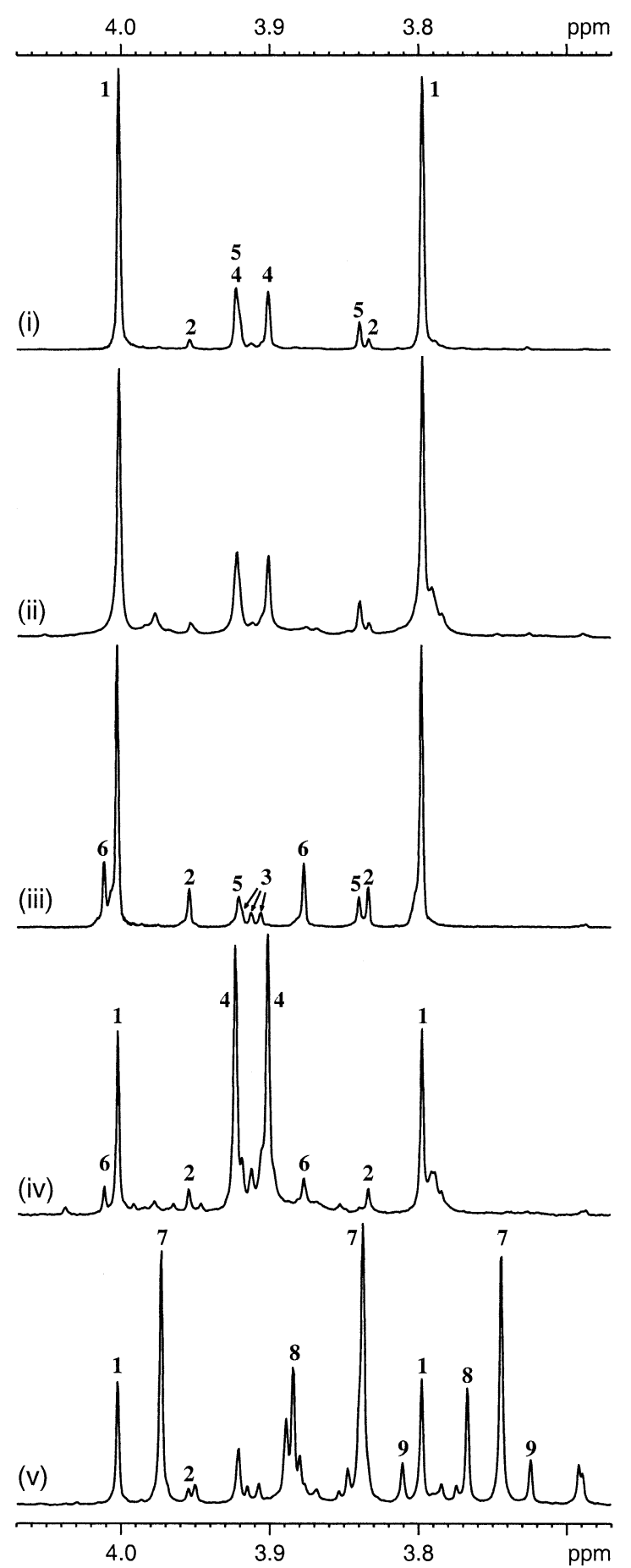

FIgURE 3. The methoxyl region of the $400 \mathrm{MHz}{ }^{1} \mathrm{H}$ NMR spectra of five $\mathrm{CDCl}_{3}$ extracts. (i)-(iv) are from the Plagiochila stricta specimens in Table 1. (v) is from a $P$. spinulosa specimen for comparison (Rycroft 97137, England). The peak labels refer to structure numbers in Figure 1 and Table 1; for clarity and/or because of overlap, all peaks from a compound may not be labelled. sent (Connolly et al. 1999). The methyl lunularate derivative 1 and 3,7-dimethoxy-9,10-dihydrophenanthren-2-ol (2) are present in all the $P$. stricta extracts and have been reported from $P$. spinulosa, $P$. retrorsa (Rycroft et al. 2001), and $P$. papillifolia (Heinrichs et al. 2002c). 2,3,5-Trimethoxy-9,10dihydrophenanthrene (3), also present in extracts (i)-(iv), is known from $P$. retrorsa and $P$. papillifolia only. 3,5-Dimethoxy-9,10-dihydrophenanthren-2-ol (4), reported from $P$. retrorsa, P. papillifolia, and P. bifaria (Rycroft et al. 1999), but absent from $P$. spinulosa, is present in all but the Ecuadorian specimen (iii). 3,7-Dimethoxy-9,10-dihydrophenanthren-4-ol (5), known hitherto from $P$. spinulosa only, is present in all but the Costa Rican specimen (iv).

The NMR spectra of the two Neotropical specimens indicated the presence of an unknown compound, at a level $25 \%$ in (iii) and $15 \%$ in (iv) of the amount of compound 1. The unknown compound has one methoxyl group ( $\delta 4.01$ p.p.m.) in a similar environment to that of the ester methoxyl of 1 ( $\delta 4.00$ p.p.m.), and a second methoxyl ( $\delta 3.88$ p.p.m.) deshielded by 0.08 p.p.m. compared to that of the $p$-methoxybenzyl moiety of $\mathbf{1}$ ( $\delta 3.80$ p.p.m.). Corresponding signals in the GC-MS were not observed until these two extracts were acetylated, when a peak of appropriate intensity and with Kováts index 2,854 (compared to 2,619 for the diacetate of compound 1) gave a mass spectrum with a parent ion at $m / z 444$ (corresponding to acetylation of three hydroxyl groups in a compound with $M_{\mathrm{r}}$ 318 ) and a base peak at $m / z 137$, equivalent to one oxygen atom more than the base peak of compound 1. It is likely that the unknown compound has structure 6, a new derivative of $\mathbf{1}$ where the benzyl moiety responsible for the base peak bears a 3-hydroxyl group as well as a 4-methoxyl. There are ten possible isomers of a hydroxymethoxybenzyl species. Comparison of the chemical shift observed for the methyl ether signal ( $\delta 3.88$ p.p.m.) with literature values enables us to reject seven of these immediately, but distinguishing between the 3-hydroxy-4methoxy-, 4-hydroxy-3-methoxy- and 2-hydroxy-3methoxy-isomers is less straightforward. The value reported by Crombie and Crombie (1982) for 3,4' dihydroxy-4,5'-dimethoxybibenzyl ( $\delta 3.88$ p.p.m.) fits perfectly and that in 3-hydroxy-3',4-dimethoxybibenzyl ( $\delta 3.86$ p.p.m.) is close (Asakawa et al. 1987). Methoxyl chemical shifts of 4-hydroxy-3methoxybibenzyls may be as large as $\delta 3.85$ p.p.m., the value reported for gigantol by Tesuka et al. (1991), although smaller values have also been reported for the same compound, e.g., $\delta 3.82$ p.p.m. by Leong et al. (1997); the latter value was reported for 4-hydroxy-3,3'-dimethoxybibenzyl by Anton et al. (1999). Values reported for 2-hydroxy-3-methoxybibenzyls, including $\delta 3.83$ p.p.m. for cirrho- 
petalidin (Majumder \& Basak 1991) and $\delta 3.87$ p.p.m. for pellepiphyllin (Cullmann et al. 1997), do not allow us to exclude this isomeric possibility. Comparison with chemical shift data in the literature is fraught with difficulties (such as uncertainties over exact measurement conditions, sample concentrations, and chemical shift references, even when these are nominally the same), especially when discrimination between small differences is required: structure $\mathbf{6}$ remains the most likely candidate but has not been proved.

Several features of the aromatic compound profile distinguish $P$. stricta from $P$. spinulosa. For example, some of the signals labelled in the ${ }^{1} \mathrm{H}$ NMR spectrum of $P$. spinulosa, Figure 3(v), arise from the major component, 2-hydroxy-3,4,7-trimethoxy9,10-dihydrophenanthrene (7), and two methyl benzoate derivatives ( $8 \& \mathbf{9})$, compounds that were not detected in $P$. stricta. None of the 9,10-dihydrophenanthrenes in $P$. stricta with an oxygen substituent at position 5 (such as $\mathbf{3}$ and $\mathbf{4}$ ) is present in $P$. spinulosa.

The monoterpene content is even more distinctive. Analysis soon after collection showed that ca $1 \% \mathrm{w} / \mathrm{w}$ of both alloocimene (10) and neoalloocimene (11) had been extracted from the plants. Two other ocimene isomers, viz. $(E)$ - $\beta$-ocimene (12) and (Z)- $\beta$-ocimene (13), were detected using GC-MS, but in quantities one and two orders of magnitude less, respectively, than the abundant isomers. These acyclic farnesatrienes are in sharp contrast to the principle monoterpene in $P$. spinulosa- $\beta$-phellandrene (14), a monocyclic menthadiene; using GCMS, $\beta$-phellandrene was not detected in any of extracts (i)-(iv) of P. stricta. This chemical difference is presumably the basis of the field observation that the odor of the crushed plant can be used to distinguish $P$. stricta and $P$. spinulosa. The only other monoterpene in $P$. stricta present in reasonable amount is terpinolene (15). There is one previous report of "ocimene" from a liverwort, from Jungermannia faureana Beauverd, but the isomeric form was not specified and the structure has been shown both as $(E)$ - $\beta$-ocimene (Asakawa et al. $1980)$ and (Z)- $\beta$-ocimene (Asakawa 1982).

In angiosperms and gymnosperms it is usual that a single enzyme takes the precursor molecule (geranyl pyrophosphate) through to the final monoterpene (Wise \& Croteau 1999). Many such monoterpene syntheses have been isolated that yield single or multiple products, although enzymes involved in the biosynthesis of ocimenes are less well known (Bohlmann et al. 2000). It has been suggested that monoterpene biosynthetic reaction mechanisms and enzymes are similar in liverworts and higher plants (Adam \& Croteau 1998). If this scenario extends to Plagiochila, then our observation of different monoterpenes in $P$. stricta and $P$. spinulosa suggests the presence of different enzymes and pathways, rather than, for example, loss in P. stricta of activity part way along a common pathway.

The remaining compounds in Table 1 are sesquiterpenoids and a diterpene that are commonly found in Plagiochila species. The only previous report of chemical constituents of P. stricta deals with a specimen from Peru determined as one of the synonyms, $P$. acanthoda Lindenb. \& Gottsche (Asakawa \& Inoue 1987). No peaks corresponding to any ocimene isomers were among the GC-MS data reported, but monoterpenes are volatile and might easily be lost from voucher specimens. The two most abundant constituents both had parent ions at $\mathrm{m} / \mathrm{z} 256$ that were also the base peak and may correspond to 9,10-dihydrophenanthrenes (such as $\mathbf{4}$ and 5) with one hydroxyl and two methoxyl substituents.

ITS nrDNA sequence analysis. - The molecular investigation produced a monophyletic lineage (Fig. 4) for P. bifaria, P. punctata, P. spinulosa, and $P$. stricta that is well supported by bootstrap analyses in all methods. The first three of these species were assigned to $P$. sect. Arrectae Carl in an earlier molecular study (Heinrichs et al. 2002b). The analyses also produced a monophyletic lineage for the four $P$. stricta sequences. While the Neotropical and the Macaronesian specimens of $P$. stricta are placed in separate clades with good bootstrap support, the differences are comparable to the variation observed between different stands of other Plagiochila species, such as $P$. porelloides (Nees) Lindenb. (Renker et al. 2002) and P. super$b a$ (Spreng.) Mont. \& Nees (Heinrichs et al. $2002 a$ ). In view of the lack of substantial phytogeographical differences in the morphological and phytochemical data, the monophyletic $P$. stricta lineage is interpreted in favor of a single species.

In order to examine the robustness of branching within the Arrectae clade, the topology of the "best tree" (Fig. 4) was compared with user-defined trees (Table 2). KH tests (Kishino \& Hasegawa 1989) clearly reject placing $P$. bifaria within the $P$. stricta clade, but do allow $P$. punctata and $P$. spinulosa to be placed there and point to the close relationship of $P$. spinulosa and $P$. stricta. The four $P$. stricta sequences differ in 29 of 802 aligned positions, the Ecuadorian and the Costa Rican specimens differ in 13, and the two Tenerife specimens in eight positions. However, the greater numbers of differences between the four $P$. stricta sequences and the $P$. spinulosa sequence (61 positions) and between the two Tenerife sequences and the $P$. spinulosa sequence (46 positions) justify separation of $P$. spinulosa from $P$. stricta.

Phytogeography.-Until 1998, only two repre- 


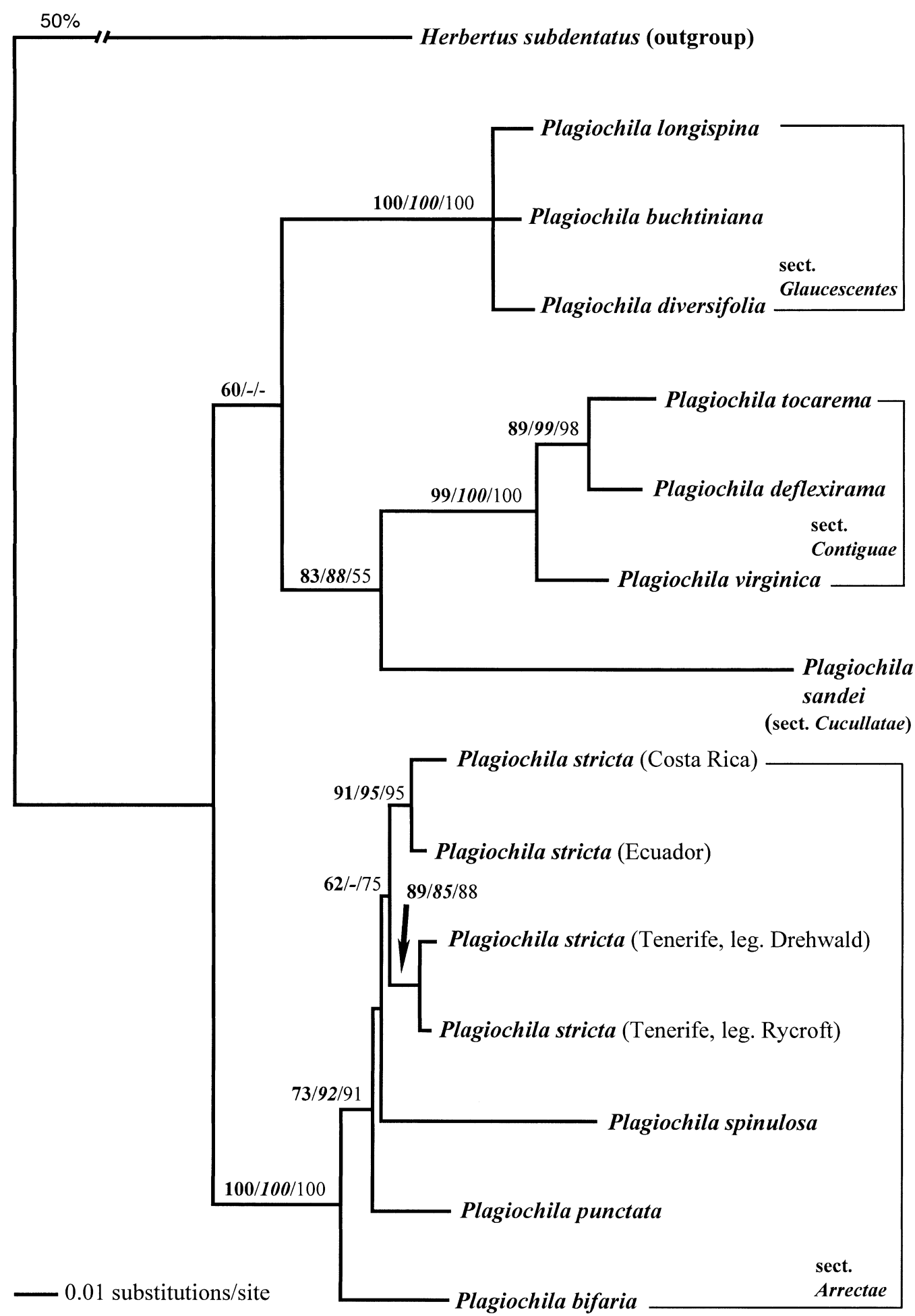

FIGURE 4. Molecular phylogeny of Plagiochila species based on ITS1-, 5.8S-, and ITS2-nrDNA sequence comparisons using 802 aligned positions. The rooted tree resulted from a maximum likelihood analysis of 15 sequences (including the outgroup), using the model of Hasegawa et al. (1985) with estimated transition/transversion ratio (Ti/Tv $=1.66)$ and estimated gamma shape $(\mathrm{G}=0.75)$, HKY $85+\mathrm{G}$, calculated as the best model by Modeltest 3.04 (Posada \& Crandall 1998); bootstrap percentage values $(>50 \%)$ were determined for maximum likelihood (using HKY85 $+\mathrm{G}$; bold), neighbor-joining (using HKY $85+\mathrm{G}$; bold italic) and unweighted maximum parsimony (not bold) methods. 
TABle 2. Comparisons of the maximum likelihood tree in Fig. 4 with user-defined trees by Kishino-Hasegawa tests (one-tailed tests) using maximum likelihood (ML) and maximum parsimony (MP) methods. ${ }^{\mathrm{a}} \mathrm{ML}$ using the HKY85+G model after Hasegawa et al. (1985), with estimated transition/transversion ratio (Ti/Tv $=1.66)$ and estimated gamma shape $(\mathrm{G}=0.75){ }^{\mathrm{b}} \Delta(-\operatorname{lnL})=$ difference in $(-\ln )$-likelihood between the best tree (Fig. 4) and the user-defined tree; ${ }^{\mathrm{c}} \mathrm{P}=$ probability of getting a more extreme $T$-value under the null hypothesis of no difference between the two trees (one-tailed test); ${ }^{\mathrm{d}} \Delta$ (length) $=$ difference in tree length between the best tree (Fig. 4) and the user-defined tree; ${ }^{\mathrm{e}}(-\mathrm{ln})-$ likelihood of the best tree (Fig. 4); flength of the optimal tree in the maximum parsimony analysis; *indicates that the user-defined tree is significantly worse than the best tree $(p<0.05)$.

\begin{tabular}{|c|c|c|c|c|}
\hline \multirow[b]{2}{*}{ Tree topology } & \multicolumn{2}{|c|}{$\mathrm{ML}^{\mathrm{a}}$} & \multicolumn{2}{|c|}{ MP } \\
\hline & $\Delta(-\operatorname{lnL})^{\mathrm{b}}$ & $\mathrm{P}^{\mathrm{c}}$ & $\Delta(\text { length })^{\mathrm{d}}$ & $\mathrm{P}^{\mathrm{c}}$ \\
\hline 1 best tree (Fig. 4 ) & $(3241.4)^{\mathrm{e}}$ & - & $(433)^{\mathrm{f}}$ & - \\
\hline $\begin{array}{l}2 P . \text { spinulosa as sister to EITHER } \\
\text { the two Neotropical OR the two } \\
\text { Macaronesian } P \text {. stricta }\end{array}$ & $1.0 \pm 1.8$ & 0.2783 & 1 & 0.3176 \\
\hline $\begin{array}{l}3 P \text {. punctata as sister to EITHER the } \\
\text { two Neotropical OR the two Maca- } \\
\text { ronesian } P \text {. stricta }\end{array}$ & $5.6 \pm 4.8$ & 0.1196 & 2 & 0.3176 \\
\hline $\begin{array}{l}4 P \text {. bifaria as sister to EITHER the } \\
\text { two Neotropical OR the two Maca- } \\
\text { ronesian } P \text {. stricta }\end{array}$ & $12.9 \pm 6.7$ & $0.0283 *$ & 8 & $0.0113^{*}$ \\
\hline $5 P$. bifaria as sister to $P$. punctata & $6.0 \pm 4.5$ & 0.0891 & 5 & $0.0253^{*}$ \\
\hline
\end{tabular}

sentatives of the genus Plagiochila were recorded from both Macaronesia and the Neotropics, and redetermination has recently removed one of these Neotropical elements from the Macaronesian flora (Heinrichs et al. 2002b). Since 1998, considerable evidence, detailed elsewhere (Heinrichs \& Rycroft 2001; Rycroft et al. 2001), has accumulated of close relationships between the Plagiochila floras of the Neotropics and Atlantic Europe (including Macaronesia). Determination of material from Tenerife as $P$. stricta has added yet another disjunct Neotropical element to the Macaronesian Plagiochila flora.

The observation that there is good bootstrap support for placing the Neotropical and Macaronesian specimens in different clades within $P$. stricta is pertinent to current interest in biogeographic patterns and cryptic speciation in bryophytes (Shaw 2001). While the similarity in morphology and phytochemistry suggest overall that the Neotropical and Macaronesian populations are conspecific (especially in the context of the species concept being applied to the on-going revision of the genus Plagiochila in the Neotropics), the available molecular data are also consistent with a hypothesis that there are two cryptic geographical taxa. More sequences are required to decide if the Macaronesian and Neotropical stands are clearly isolated genetically from each other or if the microclades break down when more sequences are included in the analyses.

\section{CONCLUSION}

Phylogenetic analyses of ITS nrDNA sequence variation place $P$. spinulosa sister to a clade containing P. stricta, and phytochemical data support separation of the two taxa. We have demonstrated that $P$. stricta, a Neotropical species, occurs on Tenerife in the Canary Islands but the question of whether $P$. spinulosa also occurs on Tenerife (and, more generally, in Macaronesia) requires further investigation.

\section{ACKNOWLEDGMENTS}

D.S.R. thanks Roy Perry for organizing the BBS Spring Field Meeting in February 2001, fellow participants (especially Gerard Dirkse and Ana Losada-Lima) for sharing knowledge of bryophytes on Tenerife, Jean Paton for herbarium material that set the ball rolling, and Bernie Cohen (IBLS Division of Molecular Genetics, University of Glasgow) for general discussions. We thank Uwe Drehwald and Ingo Holz for some of the plant material.

\section{Literature Cited}

AdAM, K.-P. \& R. CROTEAU. 1998. Monoterpenoid biosynthesis in the liverwort Conocephalum conicum: demonstration of sabinene synthase and bornyl diphosphate synthase. Phytochemistry 49: 475-480.

ADAMS, R. P. 1995. Identification of Essential Oil Components by Gas Chromatography/Mass Spectroscopy. Allured Publishing Corporation, Carol Stream, IL.

AKaIKE, H. 1974. A new look at the statistical model identification. IEEE Transactions on Automatic Control 19: 716-723.

Anton, H., R. Schoeneborn \& R. Mues. 1999. Bibenzyls and bisbibenzyls from a neotropical Plagiochila species. Phytochemistry 52: 1639-1645.

AsakawA, Y. 1982. Chemical constituents of the Hepaticae, pp. 1-285. In W. Herz, H. Grisebach \& G. W. Kirby (eds.), Progress in the Chemistry of Organic Natural Products, Vol. 42. Springer-Verlag, Wien.

- \& H. INOUE. 1987. Chemical constituents of Peruvian Plagiochila species, pp. 119-128. In H. Inoue (ed.), Studies on Cryptogams in Southern Peru. Tokai University Press, Tokyo.

, C. Suire, M. Toyota, N. Tokunaga, T. Take- 
moto, S. Hattori \& M. Mitzutani. 1980. Chemosystematics of bryophytes V. The distribution of terpenoids and aromatic compounds in European and Japanese liverworts. Journal of the Hattori Botanical Laboratory 48: 285-303.

K. TAKIKAwA \& M. ToRI. 1987. Bibenzyl derivatives from the Australian liverwort Frullania falciloba. Phytochemistry 26: 1023-1025.

Blockeel, T. L. 2002. British Bryological Society meeting on Tenerife, Canary Islands, February 2001. Bulletin of the British Bryological Society 78: 3-11.

Bohlmann, J., D. Martin, N. J. Oldham \& J. GershenZON. 2000. Terpenoid secondary metabolism in Arabidopsis thaliana: cDNA cloning, characterization, and functional expression of a myrcene/(E)- $\beta$-ocimene synthase. Archives of Biochemistry and Biophysics 375: 261-269.

COMBINEd CHemical Dictionary on CD-ROM, Version 5:1. 2001. Chapman \& Hall/CRC, Boca Raton, FL.

Connolly, J. D., D. S. Rycroft, D. L. Srivastava, W. J. Cole, P. Ifeadike, S. F. Kimbu, J. Singh, M. Hughes, C. Thom, U. Gerhard, A. J. Organ, R. J. Smith \& L. J. HARRISON. 1999. Aromatic compounds from the liverwort Plagiochila spinulosa. Phytochemistry 50: 1159-1165.

Crombie, L. \& W. M. L. Crombie. 1982. Natural products of Thailand high $\Delta^{1}$-THC-strain Cannabis. The bibenzyl-spiran-dihydrophenanthrene group: relations with cannabinoids and canniflavones. Journal of the Chemical Society, Perkin Transactions 1: 1455-1466.

Crowley, K. J. 1968. The photochemical transformations of alloocimene. Journal of Organic Chemistry 33: 3679-3686.

Cullmann, F., H. Becker, E. Pandolfi, E. Roeckner \& T. EICHER. 1997. Bibenzyl derivatives from Pellia epiphylla. Phytochemistry 45: 1235-1247.

Dirkse, G. M., A. C. Bouman \& A. Losada-Lima. 1993. Bryophytes of the Canary Islands, an annotated checklist. Cryptogamie, Bryologie Lichénologie 14: 1-47.

Felsenstein, J. 1985. Confidence limits on phylogenies: an approach using the bootstrap. Evolution 39: $783-$ 791.

Freitas, H. \& A. Brehm. 2001. Genetic diversity of the Macaronesian leafy liverwort Porella canariensis inferred from RAPD markers. Journal of Heredity 92: 339-345.

Hasegawa, M., H. Kishino \& T. Yano. 1985. Dating the human-ape splitting by a molecular clock of mitochondrial DNA. Journal of Molecular Evolution 22: $160-174$.

Heinrichs, J., S. R. Gradstein \& R. Grolle. 1998a. A revision of the Neotropical species of Plagiochila (Dumort.) Dumort. (Hepaticae) described by Olof Swartz. Journal of the Hattori Botanical Laboratory 85: 1-32. , R. Grolle \& U. Drehwald. 1998b. The conspecificity of Plagiochila killarniensis Pearson and P. bifaria (Sw.) Lindenb. (Hepaticae). Journal of Bryology 20: 495-497.

- H. Groth, S. R. Gradstein, D. S. Rycroft, W. J. Cole \& H. Anton. 2001. Plagiochila rutilans (Hepaticae): a poorly known species from tropical America. THE BRYOLOGIST 104: 350-361.

- I. Holz, D. S. Rycroft, C. Renker \& T. PRÖSCHOLD. 2002a. The systematic position of Plagiochila moritziana, $P$. trichostoma, and $P$. deflexa based on ITS sequence variation of nuclear ribosomal DNA, morphology, and lipophilic secondary metabolites. The Bryologist 105: 189-203.

- T. Pröschold, C. Renker, H. Groth \& D. S.
RyCROFT. 2002b. Plagiochila virginica A.Evans rather than $P$. dubia Lindenb. \& Gottsche occurs in Macaronesia; placement in sect. Contiguae Carl is supported by ITS sequences of nuclear ribosomal DNA. Plant Systematics and Evolution 230: 221-230.

\& D. S. RYCROFT. 2001. Leaf surface waxes and lipophilic secondary metabolites place the endemic European liverwort Plagiochila atlantica F.Rose in the Neotropical Plagiochila sect. Bursatae Carl. Cryptogamie, Bryologie 22: 95-103.

H. Groth \& W. J. Cole. 2002c. Morphological and phytochemical studies of Plagiochila papillifolia Steph., a Neotropical liverwort new to Europe. Journal of Bryology 24: 119-126.

Johnson, G. N., F. J. Rumsey, A. D. Headley \& E. ShefFIELD. 2000. Adaptations to extreme low light in the fern Trichomanes speciosum. New Phytologist 148: 423-431.

Kishino, H. \& M. Hasegawa. 1989. Evaluation of the maximum likelihood estimate of the evolutionary tree topologies from DNA sequence data, and the branching order of the Hominoidea. Journal of Molecular Evolution 29: 170-179.

LeOng, Y.-W., C.-C. Kang, L. J. Harrison \& A. D. PowELL. 1997. Phenanthrenes, dihydrophenanthrenes and bibenzyls from the orchid Bulbophyllum vaginatum. Phytochemistry 44: 157-165.

Majumder, P. L. \& M. BASAK. 1991. Two bibenzyl derivatives from the orchid Cirrhopetalum andersonii. Phytochemistry 30: 321-324.

PAGE, R. D. M. 1996. TREEVIEW: an application to display phylogenetic trees on personal computers. Computer Applications in the Biosciences 12: 357-358.

PAtON, J. A. 1999. The Liverwort Flora of the British Isles. Harley Books, Colchester, U.K.

PosadA, D. \& K. A. Crandall. 1998. Modeltest: testing the model of DNA substitution. Bioinformatics 14: 817-818.

Ratcliffe, D. A., H. J. B. BiRKs \& H. H. BiRKs. 1993. The ecology and conservation of the Killarney Fern Trichomanes speciosum Willd. in Britain and Ireland. Biological Conservation 66: 231-247.

Renker, C., J. Heinrichs, T. Pröschold, H. Groth \& I. HoLz. 2002. ITS sequences of nuclear ribosomal DNA support the generic placement and the disjunct range of Plagiochila (Adelanthus) carringtonii. Cryptogamie, Bryologie 23: 23-29.

RYCROFT, D. S. 1996. Fingerprinting of plant extracts using NMR spectroscopy: application to small samples of liverworts. Chemical Communications: 2187-2188. 1998. Chemical comparison of liverworts using NMR spectroscopy. Journal of the Hattori Botanical Laboratory 84: 105-111.

\& W. J. Cole. 2001. Hydroquinone derivatives and monoterpenoids from the Neotropical liverwort Plagiochila rutilans. Phytochemistry 57: 479-488.

, N. Aslam, Y. M. LAmont \& R. Gabriel. 1999. Killarniensolide, methyl orsellinates and 9,10dihydrophenanthrenes from the liverwort Plagiochila killarniensis from Scotland and the Azores. Phytochemistry 50: 1167-1173.

— J. Heinrichs, W. J. Cole \& H. Anton. 2001. A phytochemical and morphological study of the liverwort Plagiochila retrorsa Gottsche, new to Europe. Journal of Bryology 23: 23-34.

SHAw, A. J. 2001. Biogeographic patterns and cryptic speciation in bryophytes. Journal of Biogeography 28: 253-261.

SwOFFORD, D. L. 2000. PAUP*, phylogenetic analysis us- 
ing parsimony (* and other methods). Version 4.0b8. Sinauer Associates, Sunderland, MA.

Tesuka, Y., H. Hirano, T. Kikuchi \& G.-J. Xu. 1991.

Constituents of Ephemerantha lonchophylla; isolation and structure elucidation of new phenolic compounds, ephemeranthol-A, ephemeranthol-B, and ephemeranthroquinone, and of a new diterpene glucoside, ephemeranthoside. Chemical and Pharmaceutical Bulletin 39: 593-598.
Wise, M. L. \& R. Croteau. 1999. Monoterpene biosynthesis, pp. 97-153. In D. E. Cane (ed.), Comprehensive Natural Products Chemistry. Elsevier Science, Oxford.

ms. received Dec. 21, 2001; accepted March 1, 2002. 